\title{
The effect of nanoparticles size on photocatalytic and antimicrobial
}

\section{properties of $\mathrm{Ag}-\mathrm{Pt} / \mathrm{TiO}_{2}$ photocatalysts}

\author{
Anna Zielińska-Jurek ${ }^{1,{ }^{*}}$, Zhishun $\mathrm{Wei}^{3}$, Izabela Wysocka ${ }^{1}$, Piotr Szweda ${ }^{2}$, Ewa Kowalska \\ ${ }^{1}$ Department of Chemical Technology, Faculty of Chemistry, Gdansk University of Technology, 80-233 \\ Gdansk, Poland \\ ${ }^{2}$ Department of Pharmaceutical Technology and Biochemistry, Faculty of Chemistry, Gdansk University of \\ Technology \\ ${ }^{3}$ Catalysis Research Center, Hokkaido University, N21, W10, 001-0021, Sapporo, Japan
}

\begin{abstract}
Ag-Pt - modified $\mathrm{TiO}_{2}$ nanocomposites were synthesized using the sol-gel method. Bimetallic modified $\mathrm{TiO}_{2}$ nanoparticles exhibited improved photocatalytic activity under visible-light irradiation, better than monometallic $\mathrm{Ag} / \mathrm{TiO}_{2}$ and $\mathrm{Pt} / \mathrm{TiO}_{2}$ nanoparticles (NPs). All modified powders showed localized surface plasmon resonance (LSPR) in visible region. The photocatalysts' characteristics by X-ray diffractometry (XRD), scanning transmission electron microscopy (STEM), diffuse reflectance spectroscopy (DRS), X-ray photoelectron spectroscopy (XPS), nitrogen adsorption (BET method for specific surface area) showed that sample with the highest photocatalytic activity had anatase structure, about $93 \mathrm{~m}^{2} / \mathrm{g}$ specific surface area, maximum plasmon absorption at ca. $420 \mathrm{~nm}$ and contained small NPs of silver of $6 \mathrm{~nm}$ and very fine platinum NPs of $3 \mathrm{~nm}$. The photocatalytic activity was estimated by measuring the decomposition rate of phenol in $0.2 \mathrm{mM}$ aqueous solution under Vis and UV/Vis light irradiation. It was found that size of platinum was decisive for the photocatalytic activity under visible light irradiation, i.e., the smaller Pt NPs were, the higher was photocatalytic activity. While, antimicrobial activities, estimated for bacteria E. coli and St. aureus, and pathogenic fungi belonging to
\end{abstract}

\footnotetext{
${ }^{1}$ Author to whom correspondence should be addressed. e-mail: annjurek@pg.gda.pl, tel: 4858 3472937, fax: 4858 3472065, ul. Narutowicza 11/12, 80-233 Gdansk, Poland
} 
Candida family, were only observed for photocatalysts containing silver, i.e., $\mathrm{Ag} / \mathrm{TiO}_{2}$ and $\mathrm{Ag}-\mathrm{Pt} / \mathrm{TiO}_{2}$ nanocomposites.

Keywords: $\mathrm{Ag}-\mathrm{Pt} / \mathrm{TiO}_{2}$, heterogeneous photocatalysis, plasmonic NPs, antimicrobial activity, silver nanoparticles, platinum

\section{Introduction}

Photocatalytic reactions at the surface of titanium dioxide have been attracting much attention in view of their practical applications to environmental cleaning, such as: selfcleaning surfaces, water, wastewater and air purification, bacteria inactivation, hydrogen generation and $\mathrm{CO}_{2}$ photoconversion to methane and low hydrocarbons. Nevertheless, due to large band gap of pure $\mathrm{TiO}_{2}$ (from 3.0 to $3.2 \mathrm{eV}$ depending on the crystal structure), it could be activated only by UV irradiation, limiting the utilization of sunlight as an irradiation source in photocatalytic reactions. To improve the efficiency of solar-driven photocatalysis, a variety of organic [1-2] and inorganic compounds [3-4] were examined as dopants or surface modifiers. Recently, noble metal nanoparticles exhibiting plasmonic properties (localized surface plasmon resonance, LSPR) have attracted attention, since they may also activate wide bandgap semiconductors (e.g. $\left.\mathrm{TiO}_{2}\right)$ towards visible-light.

An appearance of activity under visible-light after modification of titania with plasmonic nanoparticles (NPs) such as gold, silver, platinum and palladium, is caused by participation of metal in a mechanism of electron transfer. The photons are absorbed by metallic NPs through their Localized Surface Plasmon Resonance (LSPR) excitation. The electron is transferred from plasmonically excited noble metal to conduction band of titania and consecutively to adsorbed oxygen. At the same time organic molecule is oxidized either by electron-deficient metal in order to return to its metallic state or/and by $\mathrm{O}_{2}{ }^{\cdot-}[5,6]$. Under UV irradiation noble metal nanoparticles deposited on $\mathrm{TiO}_{2}$ enhance the transfer of photogenerated electrons prolonging charge carriers lifetime. The activation mechanism of 
the noble metal modified $\mathrm{TiO}_{2}$ particles in the $\mathrm{UV}$ range is mainly based on the formation of Schottky barrier [6].

The enhancement in reactivity was first observed by Sato et al. for the photoconversion of $\mathrm{H}_{2} \mathrm{O}$ to $\mathrm{H}_{2}$ using the $\mathrm{Pt} / \mathrm{TiO}_{2}$ system [7]. Metals (such as $\mathrm{Pt}, \mathrm{Au}, \mathrm{Ag}$ ) and the semiconductor $\left(\mathrm{TiO}_{2}\right)$ have different Fermi level positions. The electron migration from the $\mathrm{TiO}_{2}$ to the metallic nanoparticle occurs until the two Fermi levels are aligned since the metal has a work function $(\phi \mathrm{m})$ higher than that of the $\mathrm{TiO}_{2}(\phi s)$. The electrical contact has formed a space charge layer so called the Schottky barrier, which trapped electrons and suppressed electron-hole recombination [6-8]. The surface of the metal acquires an excess negative charge, while the $\mathrm{TiO}_{2}$ exhibits an excess positive charge as a result of electron migration away from the barrier region. The height of the barrier $(\phi b)$ is defined as the difference between the $\mathrm{TiO}_{2}$ conduction band and the metal Fermi level. Electrons drawn across this barrier leaves additional positive holes in the $\mathrm{TiO}_{2}$ matrix capable of oxidizing more organic species.

Efficiency of (photo)catalytic process depends strongly on particle size and shape of noble metal deposits, therefore control of structural properties of metallic nanoparticles is critical to photocatalytic and antimicrobial activity. It was reported that small and monodispersed silver nanoparticles ranging from 5 to $10 \mathrm{~nm}$ exhibited the highest photocatalytic and antimicrobial activity [9]. However, for gold nanoparticles deposited on titania an increase in gold NPs size resulted in enhancement of photocatalytic activity, probably due to the ability of photoabsorption of more photons by larger and rod-like gold nanoparticles of broad plasmonic absorption band [5, 10]. In contrary, a considerable increase of photocatalytic activity was observed for small bimetallic NPs of Ag-Au and Pt$\mathrm{Pd}\left(2\right.$ to $5 \mathrm{~nm}$ ) deposited on $\mathrm{TiO}_{2}$, e.g., bimetallic modified titania (1.5 mol\% Ag and 0.5 mol\% $\mathrm{Au}$ ) decomposed phenol three and two times faster than titania single modified with 
$\mathrm{Au}$ and $\mathrm{Ag}$, respectively $[10,11]$. Therefore, nano-architecture arrangement (shape and size of noble metal) as well as selection of noble metal and titania form may allow preparing the photoactive catalysts under overall solar spectrum [12].

In the present study we have examined the effect of surface properties of $\mathrm{Ag}-\mathrm{Pt} / \mathrm{TiO} \mathrm{O}_{2}$ photocatalysts on the antimicrobial activity and efficiency of phenol degradation under $\mathrm{UV} / \mathrm{Vis}$ and Vis $(\lambda>420 \mathrm{~nm})$ light irradiation. Platinum is one of the most active metals for photocatalytic enhancement under UV irradiation, which can produce the highest Schottky barrier among metals facilitating electron capture, and therefore hindering the recombination between electrons and holes [13]. While, Ag particles dispersed on the surface of $\mathrm{TiO}_{2}$ could greatly enhance photocatalytic and antimicrobial activity.

The effect of properties of noble metal and titania, i.e., amount and size of noble metal, specific surface area, particle size and polymorphic form of titania, on the efficiency of removal of model organic compound and model microorganisms from aqueous phase have been systematically investigated.

\section{Experimental}

\subsection{Materials and instruments}

Titanium isopropoxide (pure p.a.) was purchased from Aldrich and used as titanium source for the preparation of $\mathrm{TiO}_{2}$ NPs. Such obtained titania and commercial $\mathrm{TiO}_{2}$ : ST-01 anatase (particle size: $8 \mathrm{~nm}, \mathrm{~S}_{\mathrm{BET}}=250 \mathrm{~m}^{2} \mathrm{~g}^{-1}$, supplier: Ishihara Sangyo Ltd., Japan), P25 (a mixture of the crystalline phases: anatase (73-85\%), rutile (14-17\%), and amorphous titania (0-13\%) [14], $\mathrm{S}_{\mathrm{BET}}=50 \mathrm{~m}^{2} \mathrm{~g}^{-1}$ supplier: Evonik, Germany) were used for the preparation of Ag-Pt - modified $\mathrm{TiO}_{2}$ photocatalysts. Silver nitrate and chloroplatinic acid hexahydrate were provided by Aldrich and used as starting materials for the preparation of silver and platinum NPs. 
XRD analysis were performed using a Rigaku Intelligent X-ray diffraction system SmartLab equipped with a sealed tube X-ray generator (a copper target; operated at $40 \mathrm{kV}$ and $30 \mathrm{~mA}$ ), a D/teX high-speed position sensitive detector system and an ASC-10 automatic sample changer. Data acquisition conditions were as follows; $2 \theta$ range: $10-90^{\circ}$, scan speed: $1.00^{\circ} \mathrm{min}^{-1}$ and scan step $0.008^{\circ}$. The obtained XRD patterns were analyzed by Rigaku PDXL, a crystal structure analysis package including Rietveld analysis, installed in a computer controlling the diffractometer.

The atomic composition was examined by X-ray photoelectron spectroscopy (XPS) and scanning electron microscopy with energy dispersive X-ray spectroscopy (SEM/EDS, JEOL JSM-6360LA). Powdered samples were attached to conductive carbon paint on aluminum and a copper holder for XPS and SEM/EDS analysis, respectively, and dried overnight under vacuum. All XPS spectra were recorded on JEOL, JPC-9010MC spectrometer using $\mathrm{Mg} \mathrm{K \alpha}$ X-rays, 50 scans were carried out for $\mathrm{Ag}$ and $\mathrm{Pt}$ ranges and average data were used for analysis. For SEM/EDS measurements, average data taken from three different regions for accelerating voltage higher than $15 \mathrm{kV}$ and the working distance of $10 \mathrm{~mm}$ were used for analyses.

To characterize the light-absorption properties of modified photocatalysts, diffuse reflectance spectra (DRS) were recorded, and data were converted to obtain absorption spectra. The measurements were carried out on Jasco V-670 spectrophotometer equipped with a PIN-757 integrating sphere where the baseline was recorded using pure $\mathrm{TiO}_{2}$ as a reference.

Nitrogen adsorption-desorption isotherms were recorded at liquid nitrogen temperature (77 K) on a Micromeritics Gemini V (model 2365) and the specific surface areas were determined by the Brunauer-Emmett-Teller (BET) method. 
High-resolution transmission electron microscopic (HRTEM) measurement was performed using an electron microscope (TEM, FEI Europe, Tecnai F20 X-Twin). To obtain a suitable sample for TEM characterization $\mathrm{Ag}-\mathrm{Pt} / \mathrm{TiO} \mathrm{O}_{2}$ powder was dispersed in ethanol in an ultrasound bath for a few minutes. Some drops of suspension were deposited on carbon covered microgrid.

\subsection{Preparation of $\mathrm{Pt} / \mathrm{TiO} \mathrm{O}_{2}$ and $\mathrm{Ag}-\mathrm{Pt} / \mathrm{TiO} \mathrm{O}_{2}$ photocatalysts}

Anatase nanoparticles were prepared by hydrolysis of titanium (IV) isopropoxide (TIP). In this regard TIP was added to ethanol and the mixture was stirred for 5 min using a magnetic stirrer operating at $500 \mathrm{rpm}$. After stirring, $5.71 \mathrm{~cm}^{3}$ of water was added to the alkoxide solution by burette and white thick precipitate was formed which gradually peptized for $2 \mathrm{~h}$ to form clear sol. The rate of water addition was kept at $0.5 \mathrm{~cm}^{3} \cdot \mathrm{min}^{-1}$. The molar ratio of $\mathrm{H}_{2} \mathrm{O} / \mathrm{TIP}$ was 12 .

Such obtained titania and two commercial $\mathrm{TiO}_{2}$ : ST-01 and P25 were used for the preparation of $\mathrm{Pt} / \mathrm{TiO}_{2}$ and $\mathrm{Ag}-\mathrm{Pt} / \mathrm{TiO}_{2}$ nanoparticles.

The $\mathrm{Pt} / \mathrm{TiO}_{2}$ samples were obtained by addition of a certain amount of $\mathrm{H}_{2} \mathrm{PtCl}_{6}$ for different nominal amounts of deposited $\mathrm{Pt}\left(0.1\right.$ or $0.5 \mathrm{~mol} \%$ calculated to $\left.\mathrm{TiO}_{2}\right)$ into $\mathrm{TiO}_{2}$ gel or $\mathrm{TiO}_{2}$ slurry dispersed in ethanol. The $\mathrm{Ag} / \mathrm{TiO}_{2}$ samples containing from 2.5 to $6.5 \mathrm{~mol} \%$ of $\mathrm{Ag}$ were prepared by adding silver precursor $\left(\mathrm{AgNO}_{3}\right)$ aqueous solution at room temperature into $\mathrm{TiO}_{2}$ dispersed in ethanol. After 30 min of mixing, reduction of metal cations by $5-\mathrm{cm}^{3} \mathrm{NaBH}_{4}$ aqueous solution was performed and obtained NPs were 1-hour aging. The molar ratio of $\mathrm{NaBH}_{4}$ to metal ions equaled to 3 .

All Ag-Pt - modified $\mathrm{TiO}_{2}$ samples were obtained by the sequential addition of $\mathrm{H}_{2} \mathrm{PtCl}_{6}$ and then $\mathrm{AgNO}_{3}$ into $\mathrm{TiO}_{2}$. Samples $\mathrm{Ag}-\mathrm{Pt} / \mathrm{TiO}{ }_{2} \mathrm{~T} 1-\mathrm{T} 5$ were obtained without using reducing agent. Precipitated $\mathrm{Ag}-\mathrm{Pt} / \mathrm{TiO}_{2}$ particles were centrifuged (2000 rpm for $5 \mathrm{~min}$ ), dried at $70^{\circ} \mathrm{C}$ for $48 \mathrm{~h}$ and calcinated at $400^{\circ} \mathrm{C}$ for $3 \mathrm{~h}$. For $\mathrm{Ag}-\mathrm{Pt} / \mathrm{TiO}_{2} \mathrm{R} 1-\mathrm{R} 3$ samples, 
sodium borohydride was used as a reducing agent with the molar ratio of $\mathrm{NaBH}_{4}$ to silver and platinum ions equaled to $3: 1$.

\subsection{Measurements of photocatalytic activity}

The photocatalytic activity of $\mathrm{Ag} / \mathrm{TiO}_{2}, \mathrm{Pt} / \mathrm{TiO}_{2}$ and $\mathrm{Ag}-\mathrm{Pt} / \mathrm{TiO}_{2}$ powders was estimated by measuring the decomposition rate of phenol aqueous solution in the presence of visible and UV/Vis irradiation. Phenol was selected as a model pollutant since it is a non-volatile and common contaminant frequently present in industrial wastewaters. The mechanism of phenol decomposition is also well established $[15,16] .25 \mathrm{~cm}^{3}$ of $2.1 \cdot 10^{-4}$ M phenol solution containing $125 \mathrm{mg}$ suspended photocatalyst was stirred using a magnetic stirrer and was continuously aerated $\left(5 \mathrm{dm}^{3} / \mathrm{h}\right)$ prior and during the photocatalytic process. The suspension was irradiated using a Xenon lamp $(6271 \mathrm{H}$, Oriel) emitting both UV and Vis light. The light flux at UV range $(310-380 \mathrm{~nm})$ was $85 \mathrm{~mW} / \mathrm{cm}^{2}$. The $25-\mathrm{cm}^{3}$ photoreactor of 3-cm thickness of exposure layer was equipped with a quartz window. The optical path included a water filter and a cut-off glass filter (GG 420, $\lambda>420 \mathrm{~nm}$ ). The temperature of the aqueous phase during irradiation was kept at $10^{\circ} \mathrm{C}$ using a water bath. Aliquots of $1 \mathrm{~cm}^{3}$ of the aqueous suspension were collected at regular time periods during irradiation and filtered through syringe filters $(\varnothing=0.2 \mu \mathrm{m})$ to remove the photocatalyst particles. Phenol concentration was estimated by colorimetric method using a UV-Vis spectrophotometer (DU-7, Beckman). Photocatalytic degradation runs were preceded by blind test in the absence of a photocatalyst or illumination. No degradation of phenol was observed in the absence of either the photocatalyst or illumination.

\subsection{Measurements of bioactivity (antibacterial and antifungal)}

MIC (minimal inhibitory concentration)

Antibacterial and antifungal activity was determined by the microtiter plate method of serial twofold dilutions, in Mueller Hinton Broth 2 medium (MHB2, Sigma) and in 
RPMI 1640 medium (with L - glutamine and phenol red, without bicarbonate) buffered with MOPS (Sigma) and supplemented with D-glucose to a final concentration of $2 \%$, respectively. Plates containing serially diluted compounds (suspended $\mathrm{Ag} / \mathrm{TiO} 2, \mathrm{Pt} / \mathrm{TiO}_{2}$ and $\mathrm{Ag}-\mathrm{Pt} / \mathrm{TiO}_{2}$ ) and compound-free control were inoculated with overnight cultures of tested strains to the final concentration of $10^{4} \mathrm{cfu} / \mathrm{cm}^{3}$ for C. albicans and $10^{6} \mathrm{cfu} / \mathrm{cm}^{3}$ for both bacterial strains. Then, plates were incubated for $24 \mathrm{~h}$ at $37^{\circ} \mathrm{C}$ and $30^{\circ} \mathrm{C}$ for antibacterial and antifungal activity determination, respectively. Microbial growth was quantified in each well by the measurement of an optical density at $\lambda=531 \mathrm{~nm}$ using the microplate reader $\left(\right.$ Victor $^{3} \mathrm{~V}$, PerkinElmer). The antimicrobial activity of $\mathrm{TiO}_{2}$ nanocomposites was estimated using Escherichia coli ATCC 10536, Staphylococcus aureus ATCC 6538 and Candida albicans.

\section{Zones of inhibition}

The solid RPMI (Sigma) (RPMI broth supplemented with bacteriological agar to a final concentration of $2 \%$ ) or Tryptic Soy Agar (BTL) was liquefied by warming at $100^{\circ} \mathrm{C}$ and then chilled to $40^{\circ} \mathrm{C}$. The semi-liquid medium was inoculated with $3 \times 10^{5} \mathrm{cells}^{\cdot} \mathrm{cm}^{-3}$ of an overnight culture of microbial cells, poured into Petri plates and left for solidification. The photocatalysts were suspended in dimethyl sulfoxide (DMSO) to create a concentration of $4 \mathrm{mg} \cdot \mathrm{cm}^{-3}$. Suspension $\left(0.02 \mathrm{~cm}^{3}\right)$ was spotted onto the agar medium surface (diameter of each spot $\sim 5 \mathrm{~mm}$, five spots on each plate). Plates were incubated for $24 \mathrm{~h}$ at $37^{\circ} \mathrm{C}$ (antibacterial activity determination) or at $30^{\circ} \mathrm{C}$ (antifungal activity determination). Growth inhibition zones appearing around the spots were measured.

\section{Results and discussion}

\subsection{Absorption properties}

The modified photocatalysts were light yellow, yellow and grey as shown in Table 1. The optical properties of $\mathrm{Ag}-\mathrm{Pt} / \mathrm{TiO}_{2}$ nanoparticles were studied by DRS and obtained data are 
shown in Fig. 1. Ag and Pt nanoparticles exhibited plasmon bands with maxima at around $395 \mathrm{~nm}$ and $400 \mathrm{~nm}$, respectively. For $\mathrm{Ag}-\mathrm{Pt} / \mathrm{TiO}_{2}$ nanoparticles it should be pointed out that depending on $\mathrm{TiO}_{2}$ source (ST-01, P25 or $\mathrm{TiO}_{2}$ from TIP hydrolysis) Ag-Pt/TiO exhibited absorption extended into the visible region over the range of $360 \sim 600 \mathrm{~nm}$. The maximal absorption for the $\mathrm{Ag}-\mathrm{Pt} / \mathrm{TiO}_{2}$ nanoparticles appeared mainly at $400-410 \mathrm{~nm}$. However, due to overlapping of LSPR peaks for Ag and Pt nanoparticles it was difficult to match unequivocally LSPR peaks as an alloy, composite nanostructure or individual NPs. Samples $\mathrm{Ag}-\mathrm{Pt} / \mathrm{TiO}_{2} \mathrm{~T} 1$ and $\mathrm{Ag}-\mathrm{Pt} / \mathrm{TiO}_{2} \_\mathrm{T} 2$ revealed a relatively narrow absorption between 395 and $400 \mathrm{~nm}$, while Ag-Pt/TiO ${ }_{2}$ T3, Ag-Pt/TiO ${ }_{2}$ R2 and Ag-Pt/TiO ${ }_{2}$ R3 exhibited a more substantial and broader absorption shoulder up to $800 \mathrm{~nm}$. The broad LSPR peak indicates the variety of size of deposited metallic NPs. The most intense absorption of light in the visible spectrum revealed the samples Ag-Pt/TiO ${ }_{2} \mathrm{~T} 3$ and $\mathrm{Ag}$ $\mathrm{Pt} / \mathrm{TiO}_{2} \_\mathrm{T} 4$. Nanocomposites of $\mathrm{Ag}-\mathrm{Pt} / \mathrm{TiO}_{2} \_\mathrm{T} 3$ and $\mathrm{Ag}-\mathrm{Pt} / \mathrm{TiO}{ }_{2} \_\mathrm{R} 2$ showed two absorption peaks at $370 \mathrm{~nm}$ (less intense) and at $420 \mathrm{~nm}$ (main peak). These samples were obtained by deposition of metal nanoparticles on commercial $\mathrm{TiO}_{2}$ (P25, Evonik). The absorption shoulder at the shortest wavelengths corroborated presence of smaller nanoparticles, though, the main absorption/extinction spectral features were dominated by the largest volume nanoparticles. Larger particles exhibit increased scattering and have peaks that broaden significantly and shift towards longer wavelengths. It was previously reported, e.g., for $\mathrm{Au}-\mathrm{Cu} / \mathrm{TiO}_{2}$ nanocomposites, that plasmon band was sensitive to the environment and could be shifted depending on the stabilizer and on the substrate [17].

\subsection{BET surface area analysis}

The BET surface areas of Ag- $\mathrm{Pt} / \mathrm{TiO}_{2}$ powders are given in Table 1. The surface area and average crystalline size for self-obtained pure $\mathrm{TiO}_{2}$ were $81 \mathrm{~m}^{2} \cdot \mathrm{g}^{-1}$ and $10 \mathrm{~nm}$, respectively. The deposition of Ag-Pt metal nanoparticles at the self-obtained $\mathrm{TiO}_{2}$ reduced 
the surface area from $81 \mathrm{~m}^{2} \cdot \mathrm{g}^{-1}$ to about $68 \mathrm{~m}^{2} \cdot \mathrm{g}^{-1}$ indicating the presence of larger metallic nanoparticles on $\mathrm{TiO}_{2}$. The surface area of the samples based on ST-01 varied from 109 to $188 \mathrm{~m}^{2} \cdot \mathrm{g}^{-1}$, while for pure ST-01 equaled to $250 \mathrm{~m}^{2} \cdot \mathrm{g}^{-1}$. Comparison between specific surface area and obtained photocatalytic activity (shown also in Table 1) indicates that rather other factor than specific surface area governs photocatalytic activity, e.g., crystalline size of metallic nanoparticles as will be discussed later.

\subsection{XRD analysis}

Exemplary XRD patterns of bare and modified TIP titania are shown in Figure 2. Self-prepared titania was mainly composed of anatase and small amount of brookite. The metal was hardly detected in the case of modification with only one metal, which indicates either small amount of deposited metal or small size of metallic NPs. In the case of deposition of both metals on the titania surface the presence of silver and metallic platinum was easily detected. For some samples, e.g., $\mathrm{Pt} / \mathrm{TiO}_{2} 1$ and $\mathrm{Ag}-\mathrm{Pt} / \mathrm{TiO}_{2} \mathrm{~T} 2$ the disappearance of brookite phase was noticed.

The determined crystalline sizes of metallic NPs (shown in Table 1) correspond well with change of specific surface area, e.g., the existence of larger metallic NPs than size of titania (8 nm), e.g., 69-nm $\operatorname{Ag}_{2} \mathrm{O}$, resulted in decrease of specific surface area of $\mathrm{Ag}$ $\mathrm{Pt} / \mathrm{TiO}_{2} \_\mathrm{T} 1$ from 81 to $68 \mathrm{~m}^{2} \cdot \mathrm{g}^{-1}$. While, the presence of small NPs of silver of $6 \mathrm{~nm}$ and very fine platinum of $3 \mathrm{~nm}$ resulted in an increase of specific surface area of $\mathrm{Ag}$ $\mathrm{Pt} / \mathrm{TiO}_{2} \_\mathrm{T} 2$ to $93 \mathrm{~m}^{2} \cdot \mathrm{g}^{-1}$. The difference between samples with deposited larger and smaller metallic NPs than size of titania was also easy noticed by broader and narrower LSPR peaks, respectively, as shown in Figure 1. For example, Ag-Pt/TiO 2 T2 containing higher amount of platinum than $\mathrm{Ag}-\mathrm{Pt} / \mathrm{TiO}_{2} \_\mathrm{T} 1$ ( 0.5 and $0.1 \mathrm{~mol} \%$, respectively) revealed a relatively narrower absorption band, which indicates formation of smaller nanoparticles 
of noble metals. This was proved by XRD data of 3- and 9-nm platinum NPs, and 14 and 69-nm NPs of silver oxide, for $\mathrm{Ag}-\mathrm{Pt} / \mathrm{TiO}_{2} \_\mathrm{T} 2$ and $\mathrm{Ag}-\mathrm{Pt} / \mathrm{TiO}_{2} \mathrm{~T} 1$, respectively.

Similar behavior was also noticed for samples prepared from commercial titania samples, i.e., formation of smaller and larger metallic NPs caused increase and decrease in specific surface area, respectively. The existence of various sizes of metallic NPs for Ag/Pt$\mathrm{TiO}_{2}$ T3 samples of the broadest LSPR peak was confirmed by the presence of 38-nm Pt $(1,1,1), 74-\mathrm{nm}$ Pt $(2,0,0)$, and small silver NPs of $12 \mathrm{~nm}$. The presence of very large Pt $(2,0,0)$ particles of $145 \mathrm{~nm}$ could be responsible for additional LSPR peak at long wavelength of $570 \mathrm{~nm}$ for $\mathrm{Ag}-\mathrm{Pt} / \mathrm{TiO}_{2}$ T 4 .

\subsection{Atomic composition and microscopy analyses}

Figure $3 \mathrm{a}-\mathrm{b}$ shows the TEM images of $\mathrm{Pt} / \mathrm{TiO}_{2} \_1$ and $\mathrm{Pt} / \mathrm{TiO}_{2} \_2$ photocatalysts with different size of Pt NPs deposited on titania. Sample Pt/TiO ${ }_{2} 1$ contained fine monodisperse $\mathrm{Pt}$ particles with diameter of about 2-6 nm, whereas $\mathrm{Pt} / \mathrm{TiO}_{2} \_2$ had polydisperse size distribution of large (20-40 nm) and small (5-10 nm) Pt NPs deposited on titania surface. The fringe spacing, which is the interplanar separation between the growth direction planes of the nanocrystal, could be estimated as $0.235 \mathrm{~nm}$, which corresponds to the fringe spacing characteristic of Pt.

The particle size and composition of the bimetallic NPs located at the $\mathrm{TiO}_{2}$ surface was studied by STEM imaging supplemented with EDS mapping as shown in Figure $3 \mathrm{c}$-d.

The sample obtained by thermal reduction of metal ions on $\mathrm{TiO}_{2}$ surface possessed small platinum nanoparticles in the range of 1 to $3 \mathrm{~nm}$ and two kinds of silver NPs, i.e., small with diameter of about 5-10 $\mathrm{nm}$ and large aggregates in the range from 20 to $45 \mathrm{~nm}$ (biggest observed) as shown in Figure 3c. For the sample obtained by chemical reduction of silver and platinum ions using sodium borohydride, the presence of larger platinum (c.a. 
$10 \mathrm{~nm}$ ) and nano-sized (c.a. $1-5 \mathrm{~nm}$ ) silver NPs was detected (see Figure 3d) confirming XRD data.

Atomic composition and chemical characters of elements incorporated in the surface layer of Ag-Pt modified titania were investigated by XPS and SEM/EDS. The presence of platinum and silver was confirmed in all analyzed samples by SEM/EDS, as presented in Table 2. However, silver was not detected in some of the samples by XPS analysis, which indicates that either low amount of silver was deposited on titania (below detection limit) or silver was covered with platinum. The first assumption could be refuted since silver was detected by SEM/EDS of higher detection limits. Thus, it is thought that large silver particles are covered by fine platinum NPs resulting in additional light absorption at longer wavelength, as shown in Fig. 1 for $\mathrm{Ag}-\mathrm{Pt} / \mathrm{TiO}_{2} \_\mathrm{T} 3$. For Ag$\mathrm{Pt} / \mathrm{TiO}_{2} \_\mathrm{T} 1-\mathrm{T} 4$ samples two kinds of bimetallic structures could be considered, i.e., i) silver NP covered by fine platinum NPs (as has been proposed above) or ii) core(Ag)shell $(\mathrm{Pt})$ structure. It is expected that for $\mathrm{Ag}-\mathrm{Pt} / \mathrm{TiO}_{2} \_\mathrm{T} 3$ sample the core-shell should be formed since it possesses: i) fine NPs of silver (12 nm) and large NPs of platinum (38 and $74 \mathrm{~nm}$ ), ii) and two plasmonic peaks where longer one is bathochromically shifted than monometallic modified sample $\left(\mathrm{Pt} / \mathrm{TiO}_{2} \_2\right)$. Similar behavior was reported for core $(\mathrm{Au})$ shell(Ag) modified titania [12].

It should be noticed that higher amounts of platinum detected by XPS (1.8-3.1\%) than used for modification $(0.5 \%)$ was expected since surface modification of titania resulted in preparation of samples enriched with metals on the surface $[9,10,18]$. It must be pointed that though metals were detected in all samples by SEM/EDS, their amounts were usually much lower (e.g., $0.06,0.09,0.34,0.23,0.58 \%$ of platinum and $0,0,0.38$, 0.34 and $0.38 \%$ of silver for $\mathrm{Pt} / \mathrm{TiO}_{2} \_2, \mathrm{Pt} / \mathrm{TiO}_{2} \_4, \mathrm{Ag}-\mathrm{Pt} / \mathrm{TiO}{ }_{2} \mathrm{~T} 2, \mathrm{Ag}-\mathrm{Pt} / \mathrm{TiO}_{2} \_\mathrm{T} 3$ and Ag-Pt/TiO $2_{2} \mathrm{~T} 4$, respectively), than used for deposition (as shown in Table 2) for thermal 
reduction method, which indicates that only part of metallic precursor was deposited on titania.

\subsection{Photocatalytic activity of pure $\mathrm{TiO}_{2}$ and (Ag-Pt)-modified $\mathrm{TiO}_{2}$}

The kinetics of phenol photodegradation in aqueous solution under UV/Vis and Vis irradiation $(\lambda>420 \mathrm{~nm})$ in the presence of $\mathrm{Pt} / \mathrm{TiO}_{2}, \mathrm{Ag} / \mathrm{TiO}_{2}$ and $\mathrm{Ag}-\mathrm{Pt} / \mathrm{TiO}_{2}$ nanoparticles is shown in Fig. 4 and in Table 1. All modified samples showed similar photocatalytic activity under full irradiation spectrum (UV/Vis) of ca. $4.8-4 \cdot 9 \cdot 10^{-2} \mathrm{~min}^{-1}$. Those activities were slightly higher than that of pure titania, which proves reported data on participation of metallic NPs in electron scavenging, which inhibits the recombination between charge carriers [18].

Under visible light irradiation modification with Pt leads to better enhancement in the photocatalytic properties compared to modification with Ag. Fine platinum nanoparticles with diameter of about $1-3 \mathrm{~nm}$ revealed the highest activity under visible light irradiation. The apparent rate constants of the first-order kinetic of phenol photodegradation increased from $0.3 \cdot 10^{-2} \mathrm{~min}^{-1}$ to $1.24 \cdot 10^{-2} \mathrm{~min}^{-1}$ and $1.84 \cdot 10^{-2} \mathrm{~min}^{-1}$ for pure $\mathrm{TiO}_{2}, \mathrm{Pt} / \mathrm{TiO}_{2} \_1$ and $\mathrm{Pt} / \mathrm{TiO}_{2} \_3$ obtained from TIP hydrolysis, respectively.

Considering the effect of platinum particles size on the photocatalytic activity the constant rate of phenol degradation decreased to $1.06 \cdot 10^{-2} \mathrm{~min}^{-1}$ and $1.45 \cdot 10^{-2} \mathrm{~min}^{-1}$ for the samples $\mathrm{Pt} / \mathrm{TiO}_{2} \_2$ and $\mathrm{Pt} / \mathrm{TiO}_{2} \_4$ obtained by deposition of platinum on commercial $\mathrm{TiO}_{2} \mathrm{P} 25$ and ST-01, respectively. DRS data and grey colour of these samples suggested aggregation and presence of polydisperse Pt particles with size larger than $10 \mathrm{~nm}$.

Compared to pure $\mathrm{TiO}_{2}, \mathrm{Ag}-\mathrm{Pt} / \mathrm{TiO}_{2}$ samples loaded with $0.5 \mathrm{~mol} \%$ of $\mathrm{Pt}$ and 2.5 mol\% of Ag exhibited a significant increase in Vis-driven phenol degradation rate. The maximum in the photocatalytic activity under Vis light irradiation was observed for Ag$\mathrm{Pt} / \mathrm{TiO}_{2} \_\mathrm{T} 2$ sample containing small silver $(6 \mathrm{~nm})$ and small platinum $(3 \mathrm{~nm})$ nanoparticles 
and $\mathrm{Ag}-\mathrm{Pt} / \mathrm{TiO}_{2} \_\mathrm{R} 1$ with small silver $(5 \mathrm{~nm})$ and platinum $(9 \mathrm{~nm})$ nanoparticles deposited on TIP titania surface (see Figure 4). For $\mathrm{Ag}-\mathrm{Pt} / \mathrm{TiO}_{2} \_\mathrm{T} 3$ and $\mathrm{Ag}-\mathrm{Pt} / \mathrm{TiO}_{2}$ T4 samples obtained by deposition of noble metals on P25 and ST-01, respectively, the efficiency of phenol degradation was about $30 \%$ lower compared to $\mathrm{Ag}-\mathrm{Pt} / \mathrm{TiO}_{2} \mathrm{~T} 2$ sample prepared from TIP as $\mathrm{TiO}_{2}$ precursor. The sizes of metallic nanoparticles deposited on $\mathrm{TiO}_{2} \mathrm{P} 25$ (silver NPs size $12 \mathrm{~nm}$, platinum ca. $38 \mathrm{~nm}$ ) and $\mathrm{TiO}_{2}$ ST-01 (silver NPs size $2 \mathrm{~nm}$, platinum NPs size ca. $42 \mathrm{~nm}$ ) were larger than that on $\mathrm{TIP} \mathrm{TiO}_{2}$.

Although Ag-Pt/TiO ${ }_{2}$ T2 sample exhibited a narrower DRS absorption band and the sizes of metal particles were much smaller than those of $\mathrm{Ag}-\mathrm{Pt} / \mathrm{TiO}_{2} \_\mathrm{T} 1$ sample, its photocatalytic activity was almost twice higher (opposite to Au modified titania for which the larger particle size was, the larger was photocatalytic activity $[5,10])$. Present results indicate the main impact of fine platinum particles on photoactivity under visible light irradiation. While, the size of silver NPs is not so crucial because of the much lower photocatalytic activity of silver deposited on $\mathrm{TiO}_{2}$ surface. The reason of size-dependent photocatalytic activity under Vis light irradiation is presently under study.

\subsection{Antimicrobial properties}

Silver nanoparticles and silver ions have strong antimicrobial activity. The impact of silver on microorganism is related to generation of $\mathrm{Ag}$ complexes with biomolecules containing sulfur, oxygen and nitrogen such as thiols, carboxylates, amides, imidazols, indoles, and hydroxyls [19]. The images of the zone of growth inhibition for S. cerevisiae and E. coli are shown in Fig. 5. The $\mathrm{Ag} / \mathrm{TiO}_{2}, \mathrm{Ag}-\mathrm{Pt} / \mathrm{TiO}{ }_{2}$ and pure $\mathrm{TiO}_{2}$ nanoparticles are well visible as white spots labeled as: (1) sample Ag-Pt/TiO 2 T4; (2) sample Ag$\mathrm{Pt} / \mathrm{TiO}_{2} \_\mathrm{T} 3$; (3) sample Ag-Pt/TiO 2 T2; (4) $\mathrm{Pt} / \mathrm{TiO}_{2} \_3$; (5) sample $\mathrm{Ag} / \mathrm{TiO}_{2} \_$; ; (6) sample $\mathrm{Pt} / \mathrm{TiO}_{2} \_$; (7) sample $\mathrm{Ag} / \mathrm{TiO}_{2} \_3$; (8) sample $\mathrm{Ag} / \mathrm{TiO}_{2} \_2$ and (9) pure $\mathrm{TiO}_{2}$. Growth inhibition zones appearing around the spots were lined for easier detection (see Fig. 5). 
Based on the zone of inhibition analysis, shown in Table 3, it was observed that the $\mathrm{Ag} / \mathrm{TiO}_{2}$ particles (discs numbers: $4,7,8$ ) inhibited the growth of bacteria and yeast. The diameter of inhibition zone depended on amount and size of silver particles in the sample. The best antimicrobial activity was observed for $\mathrm{Ag} / \mathrm{TiO}_{2} \_1$ sample. The diameters of zones of inhibition for $\mathrm{Ag} / \mathrm{TiO}_{2} \_1$ were $9 \mathrm{~mm}$ for C. albicans, $19 \mathrm{~mm}$ for E. coli and 18 $\mathrm{mm}$ for $S$. aureus. Photocatalyst which exhibited the best efficiency of phenol degradation $\left(\mathrm{Ag}-\mathrm{Pt} / \mathrm{TiO}_{2} \_\mathrm{T} 2\right)$ containing small silver NPs $(6 \mathrm{~nm})$ and fine platinum NPs $(3 \mathrm{~nm})$ revealed only antifungal properties. The diameter of zone of inhibition measured for $C$. albicans (disc no. 3) was $11 \mathrm{~mm}$. Ag-Pt/TiO ${ }_{2} \mathrm{~T} 4$ and $\mathrm{Ag}-\mathrm{Pt} / \mathrm{TiO}_{2} \_\mathrm{R} 1-\mathrm{R} 3$ samples containing fine $(\sim 2-3 \mathrm{~nm})$ silver nanoparticles revealed higher antimicrobial activity than Ag-Pt/TiO ${ }_{2}$ T2 with larger silver NPs of 6-nm size. The Ag/TiO 2 and Ag-Pt/TiO ${ }_{2}$ samples showed higher antibacterial activity against Gram-negative bacteria E. coli than Grampositive St. aureus. The decreased susceptibility of Gram-negative bacteria can be explained by the fact that the cell wall of Gram-positive bacteria is thicker than that of Gram-negative bacteria and exhibits only a thin peptidoglycan layer $(2 \sim 3 \mathrm{~nm})$ between the cytoplasmic membrane and the outer membrane. In contrast, Gram-positive bacteria does not have the outer membrane, but possesses 30 -nm thick peptidoglycan layer, which is negatively charged, and therefore more silver species may get trapped to peptidoglycan in Gram-positive bacteria [20].

To determine the lowest concentration of photocatalyst at which complete inhibition of microorganism growth would be visible noticed, the minimum inhibitory concentration (MIC) was determined. The obtained MIC data for mono and bimetallic samples against bacteria and fungi are shown in Table 4.

For pure $\mathrm{TiO}_{2}$ and $\mathrm{Pt} / \mathrm{TiO}_{2} \_3$ sample containing $0.5 \mathrm{~mol} \%$ of $\mathrm{Pt}$, the inhibition in microorganisms' growth was not observed even for photocatalyst concentration higher 
than $250 \mu \mathrm{g} \cdot \mathrm{cm}^{-3}$. The lowest MIC value (the highest bioactivity) was observed for $C$. albicans ATCC 10231 in the presence of $\mathrm{Ag} / \mathrm{TiO}_{2} \_1$ sample containing $0.5 \mathrm{~mol} \%$ of silver. The increase in silver content to 4.5 and $6.5 \mathrm{~mol} \%$ resulted in slight increase in the MIC value, possibly due to aggregation of silver and its different distribution on $\mathrm{TiO}_{2}$ surface.

\subsection{Discussion}

Bimetallic modified $\mathrm{TiO}_{2}$ with silver and platinum NPs exhibited improved photocatalytic activity under visible-light irradiation in comparison to monometallic photocatalysts $\left(\mathrm{Ag} / \mathrm{TiO}_{2}\right.$ and $\left.\mathrm{Pt} / \mathrm{TiO}_{2}\right)$. Synergistic effect of silver and platinum nanoparticles on photocatalytic activity of $\mathrm{TiO}_{2}$ in visible light was confirmed. The best photocatalytic activity was observed for $\mathrm{Ag}-\mathrm{Pt} / \mathrm{TiO}_{2} \mathrm{~T} 2$ and $\mathrm{Ag}-\mathrm{Pt} / \mathrm{TiO}_{2} \_\mathrm{R} 1$ samples containing small NPs of silver and platinum deposited on TIP titania surface. Obtained results showed that enhanced photocatalytic activity under visible light for bimetallic Ag$\mathrm{Pt} / \mathrm{TiO}_{2}$ photocatalysts was affected by $\mathrm{Ag}$ and $\mathrm{Pt}$ nanoparticles size as well as surface properties of $\mathrm{TiO}_{2}$ matrix. Smaller platinum nanoparticles observed on the surface of $\mathrm{TiO}_{2}$ obtained from TIP hydrolysis (anatase, particles size $=10 \mathrm{~nm}, \mathrm{~S}_{\mathrm{BET}}=81 \mathrm{~m}^{2} \mathrm{~g}^{-1}$ ) and small anatase nanoparticles (ST-01, particles size $=8 \mathrm{~nm}, \mathrm{~S}_{\mathrm{BET}}=250 \mathrm{~m}^{2} \mathrm{~g}^{-1}$ ) revealed higher photocatalytic activity than larger platinum nanoparticles obtained by deposition on $\mathrm{TiO}_{2}$ P25 support (mixture of anatase, rutile and amorphous titania, particles size ca. $30 \mathrm{~nm}$, $\mathrm{S}_{\mathrm{BET}}=55 \mathrm{~m}^{2} \mathrm{~g}^{-1}$ ). Recently, we have reported the effect of $\mathrm{TiO}_{2}$ matrix on the size of noble metal nanoparticles and photocatalytic activity [10]. For $\mathrm{Au} / \mathrm{TiO}_{2}$ nanocomposites the obtained results suggested that deposition of large gold nanoparticles $(60-110 \mathrm{~nm})$ on the surface of $\mathrm{TiO}_{2}$ resulted in enhancement of visible light photoactivity. Higher photoactivity was observed for large gold NPs deposited on the surface of small rutile or anatase $\mathrm{TiO}_{2}$ nanoparticles [10]. On the other hand, it is well known that fine nanoparticles of noble metal often improves the reaction efficiency working as a co-catalyst through: (i) 
enhancement of the electron-hole separation and thus preventing recombination of charge carriers, and (ii) extension of the light absorption into the visible range and enhancing surface electron excitation by plasmon resonance excited by visible light. Haruta et al. observed that small gold nanoparticles less than $5 \mathrm{~nm}$ in size were very active as "dark" catalysts [21]. Recently it was also found that fine platinum nanoparticles in the size range from 1 to $4 \mathrm{~nm}$ revealed the highest activity under visible light irradiation for reaction of organic pollutants degradation from aqueous stream [11]. Kohtani et al. reported that fine platinum particles loaded on photocatalyst greatly improved the efficiency of hydrogen evolution from water or alcohol under irradiation [22]. Shiraishi et al. found that Pt-Cu bimetallic nanoparticles deposited on anatase with particle size from $3 \mathrm{~nm}$ to $5 \mathrm{~nm}$ exhibited the highest photocatalytic activity [23]. Larger particles ( $>5 \mathrm{~nm}$ diameter) contained a decreased number of surface Pt atoms and therefore revealed decreased activity.

Based on literature, it is also known that platinum possesses higher affinity for the $\mathrm{TiO}_{2}$ surface compared to silver. Therefore, the size of titania determines much more the size of platinum than silver $[24,25]$. Our results have shown that smaller $(1-3 \mathrm{~nm})$ platinum NPs than silver (5-12 nm) were formed on $\mathrm{TiO}_{2}$ surface by thermal treatment method. Platinum ions interact stronger with $\mathrm{TiO}_{2}$ matrix than silver which protects them from agglomeration during thermal process. On the other hand, smaller silver nanoparticles $(\sim 5 \mathrm{~nm})$ and larger platinum NPs $(\sim 10 \mathrm{~nm})$ were obtained using sodium borohydride as a reducing agent during preparation procedure (samples $\mathrm{Ag}-\mathrm{Pt} / \mathrm{TiO}{ }_{2} \mathrm{R} 1-\mathrm{R} 3$ ).

\section{Conclusions}

For the first time, inhibition of microorganism growth and photocatalytic activity under visible light irradiation for phenol degradation on $\mathrm{Ag}-\mathrm{Pt} / \mathrm{TiO}_{2}$ photocatalysts is reported in this article. Photoactivity of $\mathrm{Pt} / \mathrm{TiO}_{2}$ and $\mathrm{Ag}-\mathrm{Pt} / \mathrm{TiO}_{2}$ powders depends mainly 
on platinum nanoparticles size. The smaller size of platinum is, the higher is efficiency of phenol degradation. The DRS, XRD, TEM and BET measurements corroborate that the most active photocatalyst under visible light $\left(\mathrm{Ag}-\mathrm{Pt} / \mathrm{TiO}_{2} \mathrm{~T} 2\right)$ contains fine $\mathrm{Pt}$ NPs $(\sim 3$ $\mathrm{nm})$ and small silver nanoparticles $(\sim 6 \mathrm{~nm})$ deposited on self-synthesized $\mathrm{TiO}_{2}$ surface. The antibacterial activities of silver nanoparticles (Ag-NPs), studied with respect to yeast C. albicans, Gram-positive St. aureus and Gram-negative E. coli, depends on content and size of silver NPs. Silver nanoparticles with size below $5 \mathrm{~nm}$ are recommended for the inhibition of pathogenic microorganisms growth.

\section{Acknowledgments}

This research was financially supported by Norway Grants in the Polish-Norwegian Research Programme (Small Grant Scheme) operated by the National Centre for Research and Development, grant no. POL-NOR/207659/23/2013 Polish-Ministry of Seience and Higher Education (grant Iuventus Plus No. IP2011063971), Bill \& Melinda Gates Foundation (Grand Challenges Explorations Grant, GCE R8, OPP1060234) and Catalysis Research Center through Target Oriented Research Assembly for "Research Cluster for Photofunctional Plasmonic Particles".

\section{References}

1. A. Fujishima, X. Zhang, Titanium dioxide photocatalysis: present situation and future approaches, Compt. Rend. Chimie 9 (2006) 750-760

2. D. Chatterjee, A. Mahata, Demineralization of organic pollutants on the dye modified $\mathrm{TiO}_{2}$ semiconductor particulate system using visible light, Appl. Catal. B 33 (2001) $119-125$

3. Z. Zhao, Q. Liu, Effects of lanthanide doping on electronic structures and optical properties of anatase $\mathrm{TiO}_{2}$ from density functional theory calculations, J. Phys. D Appl. Phys. 41 (2008) 1-10 
4. R. Asahi, T. Morikawa, T. Ohwaki, K. Aoki, Y. Taga, Visible-light photocatalysis in nitrogen-doped titanium oxides, Science 293 (2001) 269-271

5. E. Kowalska, O. Prieto Mahaney, R. Abe, B. Ohtani, Visible-light-induced photocatalysis through surface plasmon excitation of gold on titania surfaces, Phys. Chem. Chem. Phys. 12 (2010) 2344-2355

6. A. Zielińska-Jurek, Progress, challenge, and perspective of bimetallic $\mathrm{TiO}_{2}$-based photocatalysts, J. Nanomater. (2014) 1-17

7. S. Sato, J. M. White, Photodecomposition of water over $\mathrm{Pt} / \mathrm{TiO}_{2}$ catalysts, Chem. Phys. Lett. $72(1980) 83$

8. A.L. Linsebigler, G. Lu, J. T. Yates, Photocatalysis on $\mathrm{TiO}_{2}$ surfaces: principles, mechanisms, and selected results, Chem. Rev. 95 (1995) 735-758

9. A. Zielińska, A. Zaleska, E. Kowalska, J.W. Sobczak, I. Łącka, M. Gazda, B. Ohtani, J. Hupka, Silver-doped $\mathrm{TiO}_{2}$ prepared by microemulsion method: surface properties, bioand photoactivity, Sep. Purif. Technol. 72 (2010) 309-318

10. A. Zielińska-Jurek, E. Kowalska, J.W. Sobczak, W. Lisowski B. Ohtani, A. Zaleska, Preparation and characterization of monometallic $(\mathrm{Au})$ and bimetallic $(\mathrm{Ag} / \mathrm{Au})$ modified-titania photocatalysts activated by visible light, Appl. Catal. B 101 (2011) 504-514

11. A. Zielińska-Jurek, J. Hupka, Preparation and characterization of Pt/Pd-modified titanium dioxide nanoparticles for visible light irradiation, Catal. Today 230 (2014) $181-187$

12. E. Kowalska, M. Janczarek, L. Rosa, S. Juodkazis, B. Ohtani, Mono- and bi-metallic plasmonic photocatalysts for degradation of organic compounds under UV and visible light irradiation, Catal. Today 230 (2014) 131-137 
13. H-W. Chen, Young Ku, Y.-L. Kuo, Effect of $\mathrm{Pt} / \mathrm{TiO}_{2}$ characteristics on temporal behavior of o-cresol decomposition by visible light-induced photocatalysis, Water Res. $41(2007) 2069-2078$

14. B. Ohtani, O. O.O. Prieto-Mahaney, D. Li, R. Abe, What is Degussa (Evonik) P25? Crystalline composition analysis, reconstruction from isolated pure particles and photocatalytic activity test, J. Photochem. Photobiol. Chem. 216 (2010) 179-182

15. K. Okamoto, Y. Yamamoto, H. Tanaka, M. Tanaka, A. Itaya, Heterogeneous photocatalytic decomposition of phenol over $\mathrm{TiO}_{2}$ powder, Bull. Chem. Soc. Jpn. 58 (1985) 2015-2022

16. V. Augugliaro, L. Palmisano, A. Sclafani, C. Minero, E. Pelizzetti, Photocatalytic degradation of phenol in aqueous titanium-dioxide dispersions, Toxicol. Environ. Chem., 16 (1988) 89-109.

17. Z. Hai, N. El Kolli, D. B. Uribe, P. Beaunier, M. Jose-Yacaman, J. Vigneron, A. Etcheberry, S. Sorgues, C. Colbeau-Justin, J. Chena, H. Remita, Modification of $\mathrm{TiO}_{2}$ by bimetallic $\mathrm{Au}-\mathrm{Cu}$ nanoparticles for wastewater treatment, J. Mater. Chem. A. 1 (2013) 10829-10835

18. E. Kowalska, K. Yoshiiri, Z. Wei, S. Zheng, E. Kastl, H. Remita, B. Ohtani, S. Rau, Hybrid photocatalysts composed of titania modified with plasmonic nanoparticles and ruthenium complexes for decomposition of organic compounds, Appl. Catal. B, doi.org/10.1016/j.apcatb.2014.10.003

19. K. Soo-Hwan, H. Lee, D. Ryu, S. Choi, D. Lee, Antibacterial activity of silvernanoparticles against Staphylococcus aureus and Escherichia coli, Korean J. Microbiol. Biotechnol. 39 (2011) 77-85 
20. K. Gupta, R. P. Singh, A. Pandey, A. Pandey, Photocatalytic antibacterial performance of $\mathrm{TiO}_{2}$ and $\mathrm{Ag}$-doped $\mathrm{TiO}_{2}$ against $S$. aureus, P. aeruginosa and E. coli, Beilstein $\mathrm{J}$. Nanotechnol. 4 (2013) 345-351

21. M. Haruta, S. Tsubota, T. Koybayashi, H. Kageyama, M.J. Genet, B. Delmon, Lowtemperature oxidation of Co over gold supported on $\mathrm{TiO}_{2}$, alpha- $\mathrm{Fe}_{2} \mathrm{O}_{3}$, and $\mathrm{Co}_{3} \mathrm{O}_{4}, \mathrm{~J}$. Catal. 144 (1993) 175-192

22. S. Kohtani, E. Yoshioka, H. Miyabe, Photocatalytic hydrogenation on semiconductor particles, hydrogenation, Prof. Iyad Karamé (Ed.), ISBN: 978-953-51-0785-9, InTech 10 (2012), DOI: $10.5772 / 45732$

23. Y. Shiraishi, H. Sakamoto, Y. Sugano, S. Ichikawa, and T. Hirai, Pt-Cu bimetallic alloy nanoparticles supported on anatase $\mathrm{TiO}_{2}$ : highly active catalysts for aerobic oxidation driven by visible light, ACS Catalysis, 7 (2014) 9287-9297

24. Y-C Lin, H. Bai, C-H Lin, J-F Wu, Applying surface charge attraction to synthesizing $\mathrm{TiO}_{2} / \mathrm{Ag}$ composition for VOCs photodegradation, Aerosol Air Qual. Res. 13 (2013) $1512-1520$

25. S. Sakthivel, M.V. Shankar, M. Palanichamy, B. Arabindoo, D.W. Bahnemann, V. Murugesa, Enhancement of photocatalytic activity by metal deposition: characterization and photonic efficiency of $\mathrm{Pt}, \mathrm{Au}$ and $\mathrm{Pd}$ deposited on $\mathrm{TiO}_{2}$ catalyst, Water. Res. 38 (2004) 3001-3008 
Figure 1. DR-UV/Vis absorption spectra of $\mathrm{Ag}$, $\mathrm{Pt}$ and $\mathrm{Ag}-\mathrm{Pt}$ nanoparticles deposited on $\mathrm{TiO}_{2}$ surface

Figure 2. XRD patterns of bare and modified TIP titania with platinum and silver; a-anatase, b-brookite, $\mathrm{Ag}^{*}$ - silver, $\mathrm{Pt}$ - platinum NPs.

Figure 3. TEM microscopy images for $\mathrm{Pt} / \mathrm{TiO}_{2}{ }_{1}$ (a), TEM and FFT analysis for sample Pt$\mathrm{TiO}_{2} \_2$ (b), STEM image and STEM-EDS mapping images of Ag-Pt/TiO ${ }_{2}$ T2 nanoparticles (c), STEM microscopy analysis for sample Ag-Pt/TiO ${ }_{2} \_\mathrm{R} 1$

Figure 4. The effect of silver and platinum particles size and the type of $\mathrm{TiO}_{2}$ matrix used during preparation of $\mathrm{Ag}-\mathrm{Pt} / \mathrm{TiO}_{2}$ on photocatalytic activity under $\mathrm{UV}$ and visible light $(\lambda>$ $420 \mathrm{~nm}$ ).

Figure 5. Zone of inhibition for pure $\mathrm{TiO}_{2}, \mathrm{Ag}-\mathrm{TiO}_{2}$ and $\mathrm{Ag}-\mathrm{Pt} / \mathrm{TiO}_{2}$ nanoparticles, (1) sample Ag-Pt/TiO $2 \_\mathrm{T} 4 ;$ (2) sample Ag-Pt/TiO ${ }_{2} \mathrm{~T} 3 ;$ (3) sample $\mathrm{Ag}-\mathrm{Pt} / \mathrm{TiO}_{2} \mathrm{~T} 2$; (4) Pt/TiO 23 ; (5) sample $\mathrm{Ag} / \mathrm{TiO}_{2} \_$; (6) sample $\mathrm{Pt} / \mathrm{TiO}_{2} \_$; (7) sample $\mathrm{Ag} / \mathrm{TiO}_{2} \_3$; (8) sample $\mathrm{Ag} / \mathrm{TiO}_{2}{ }_{2}$ and (9) pure $\mathrm{TiO}_{2}$ 
Graphical Abstract
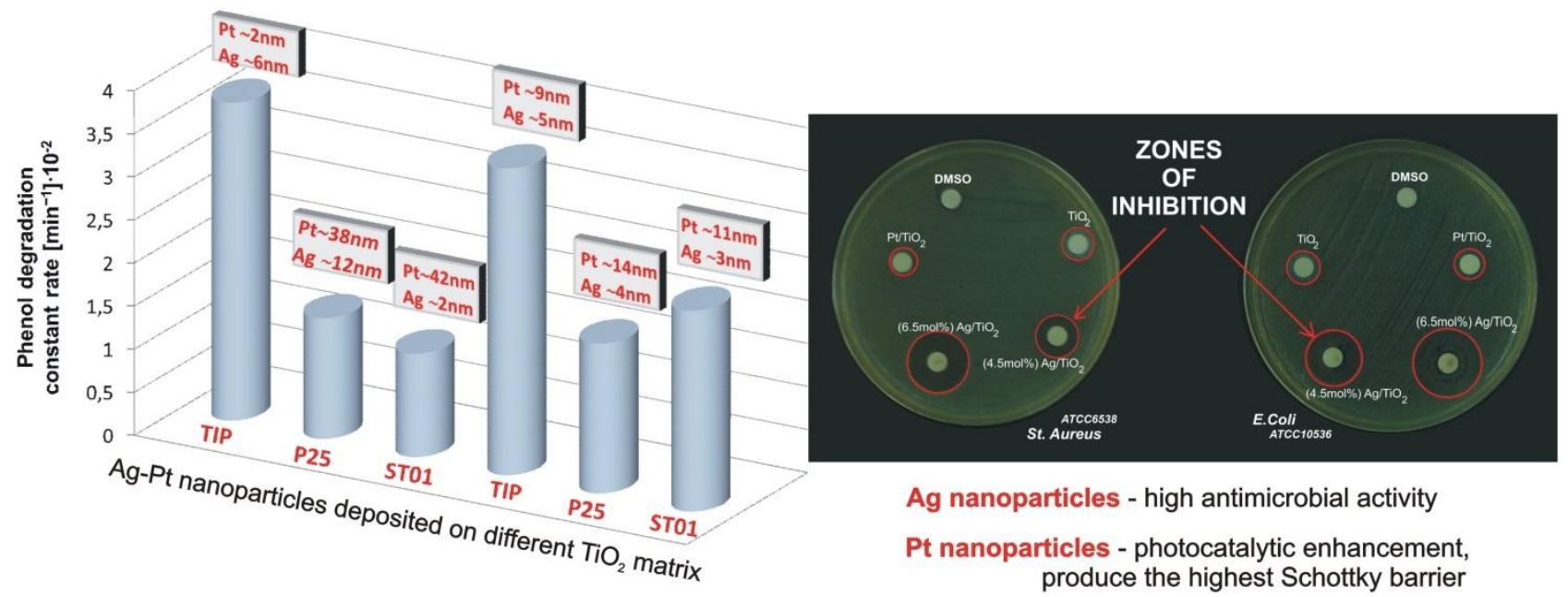

Ag nanoparticles - high antimicrobial activity Pt nanoparticles - photocatalytic enhancement,
produce the highest Schottky barrier

produce the highest Schottky barrier 


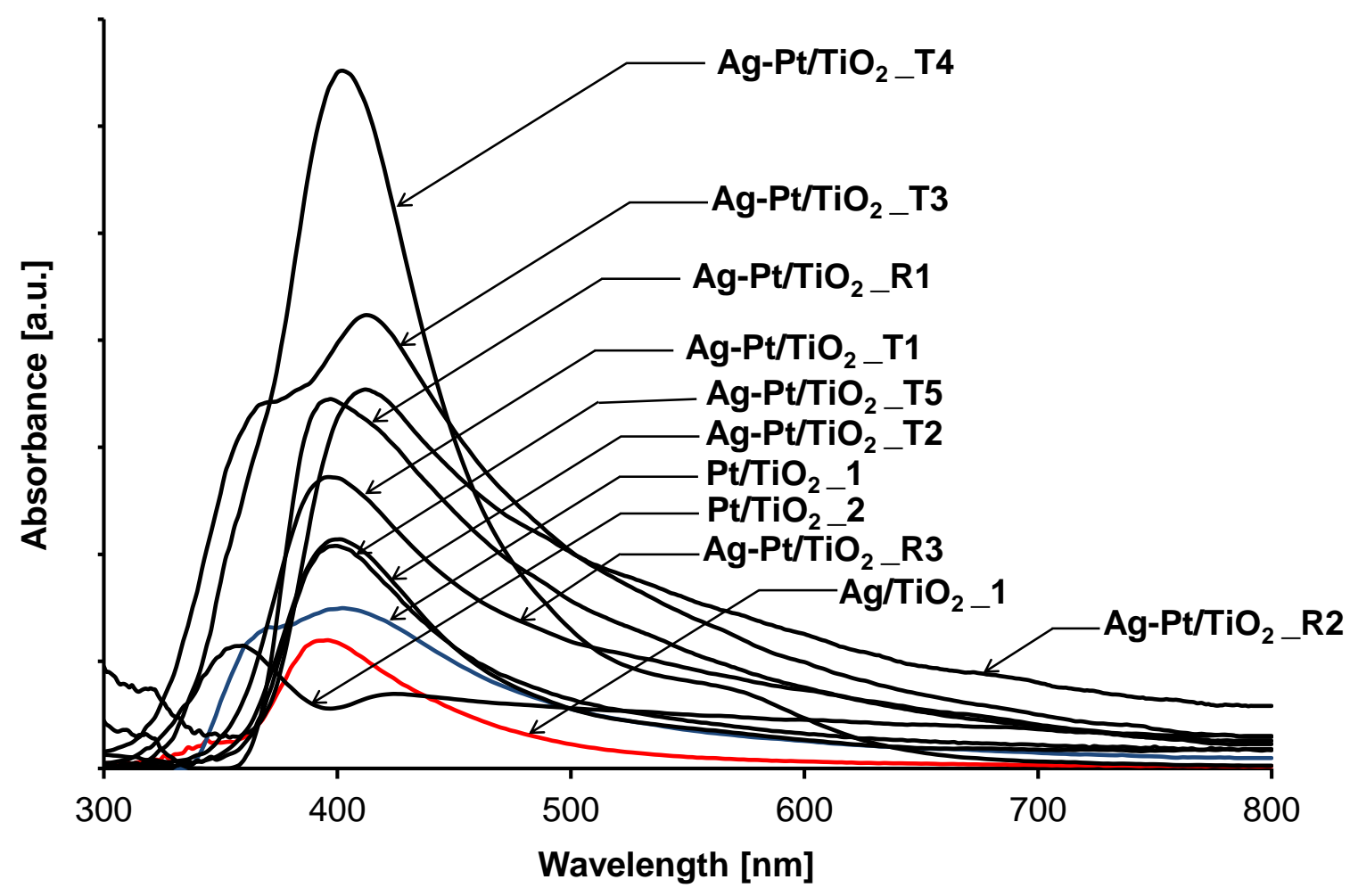


Figure 2

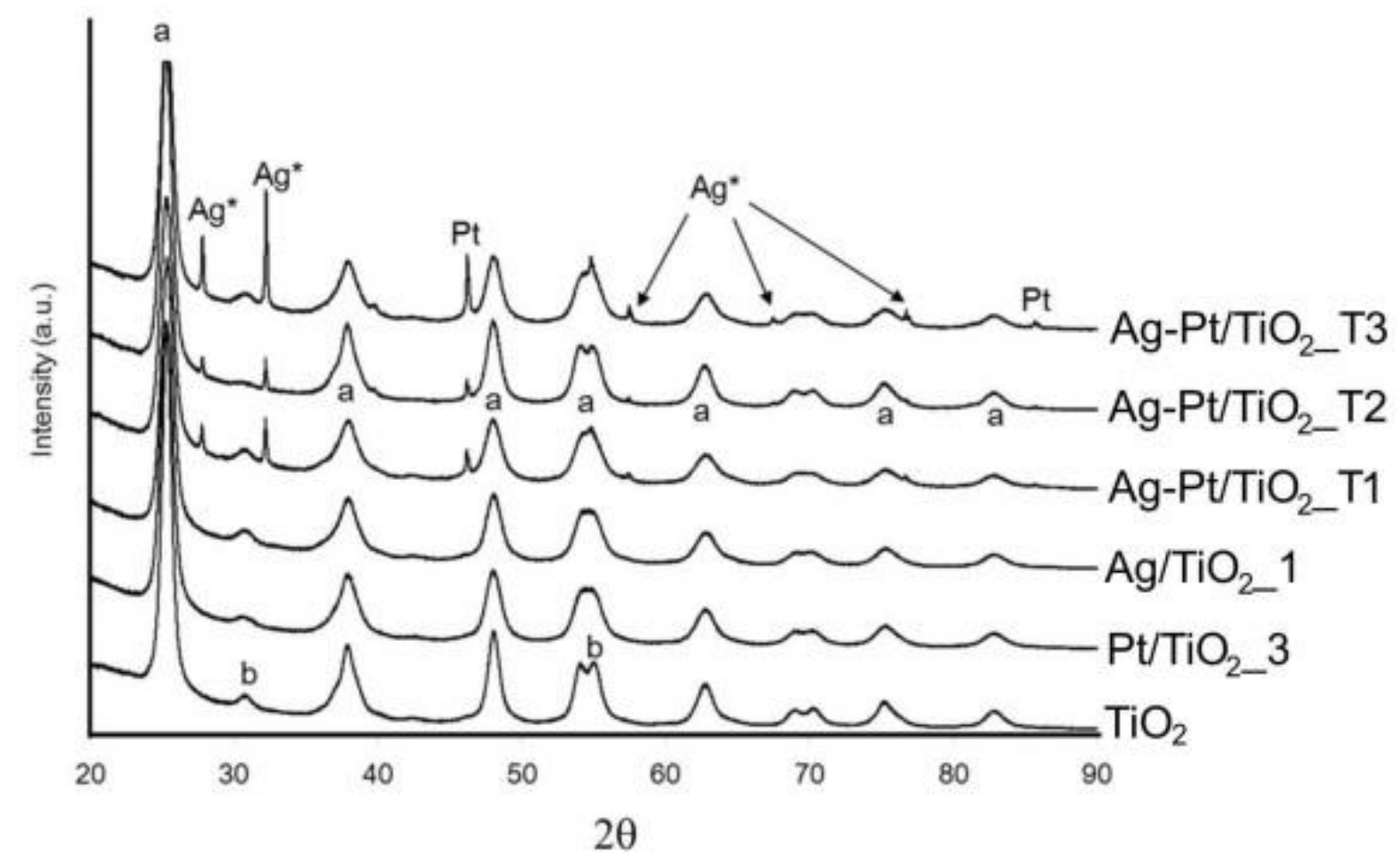


Figure 3
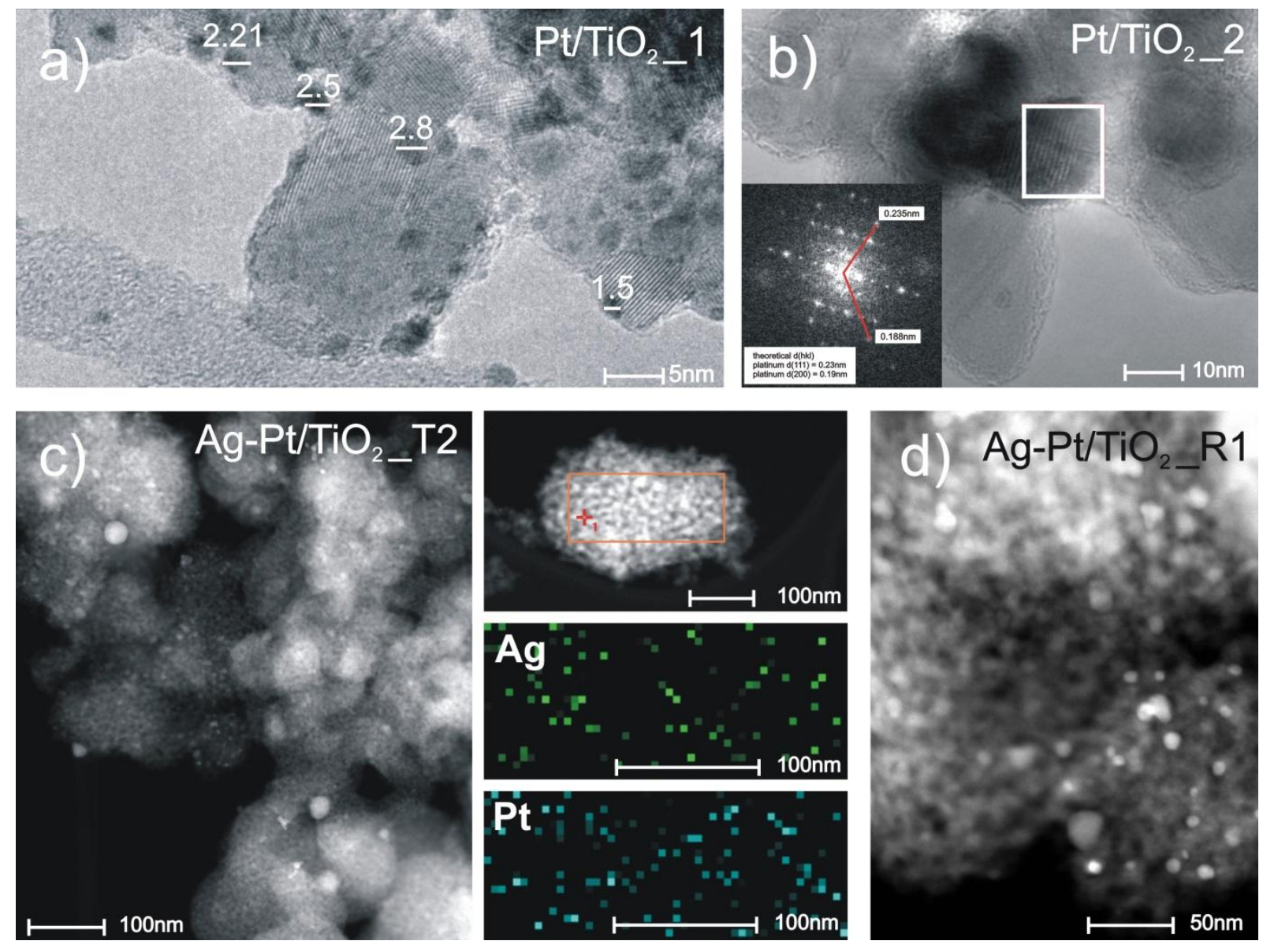
Figure 4

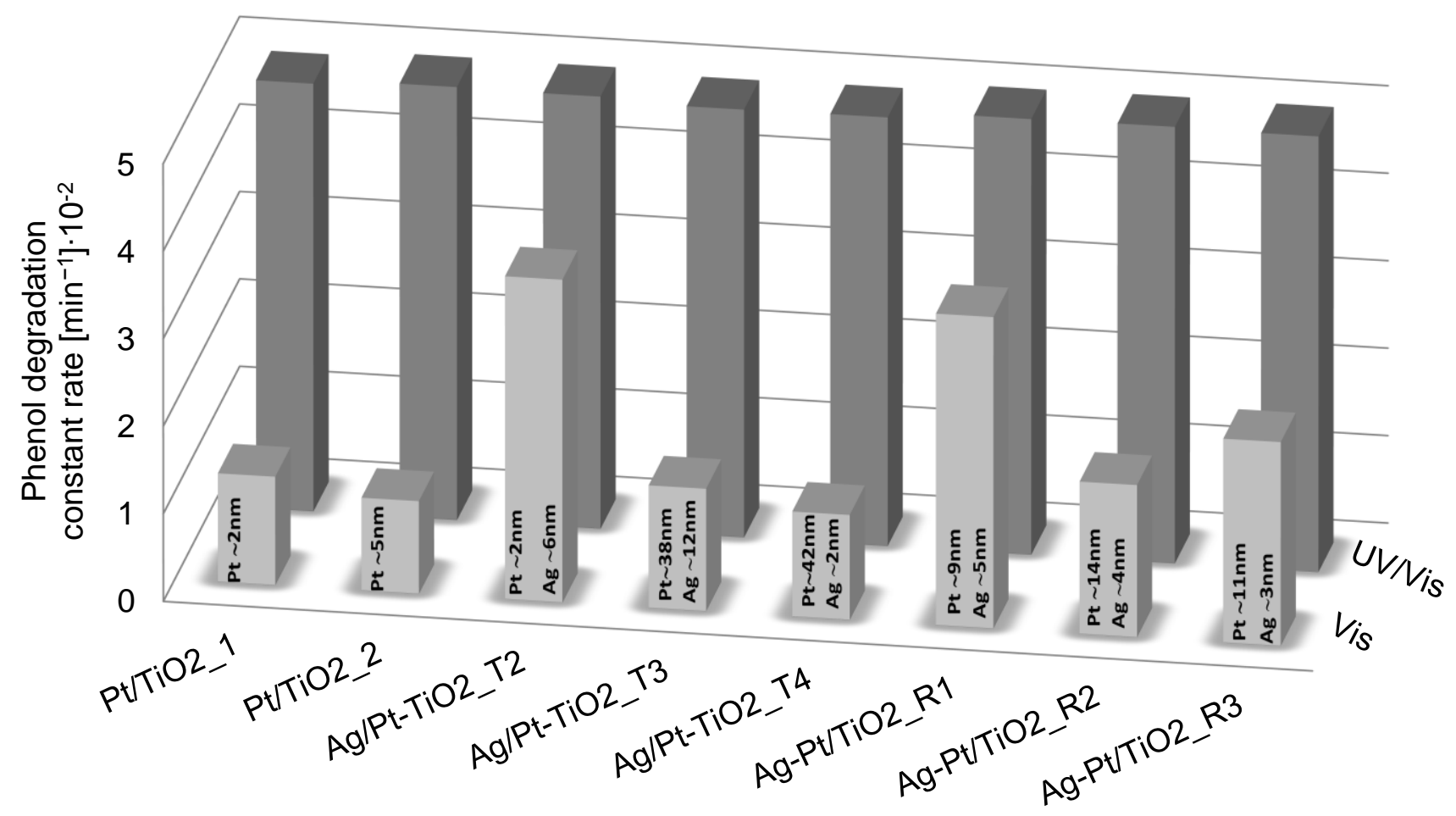


Figure 5

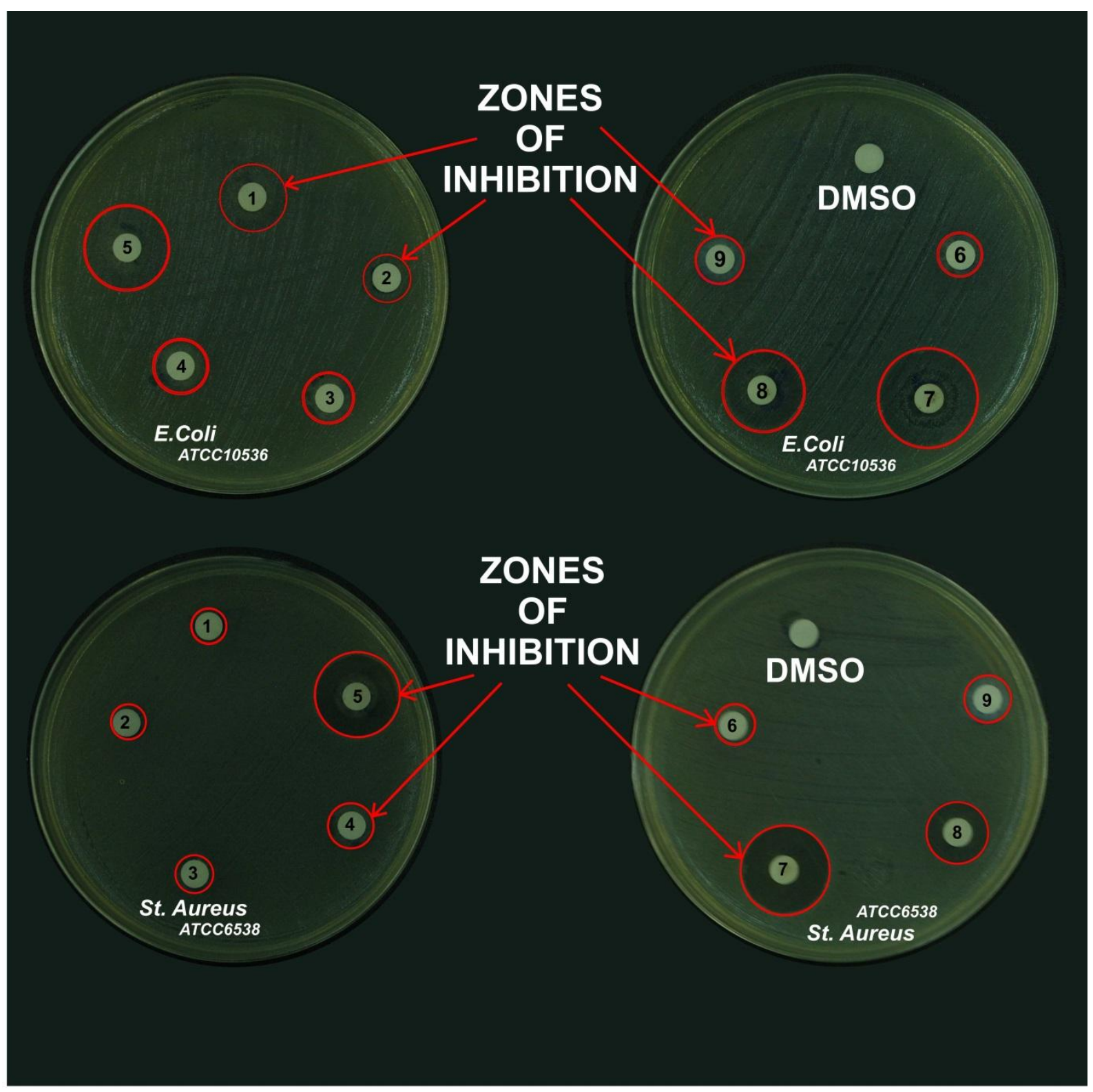


Table 1. Preparation conditions, characteristics and photoactivity of $\mathrm{Ag} / \mathrm{TiO}_{2}, \mathrm{Pt} / \mathrm{TiO}_{2}$ and $\mathrm{Ag}-\mathrm{Pt} / \mathrm{TiO}_{2}$ photocatalysts

Table 2. XPS and SEM/EDS results of the content of noble metals in modified titania samples

Table 3. Zone of inhibition for Ag-Pt/ $/ \mathrm{TiO}_{2}$ nanoparticles, diameter of zone (mm)

Table 4. Minimum inhibitory concentration for $\mathrm{Ag} / \mathrm{TiO}_{2}, \mathrm{Pt} / \mathrm{TiO}_{2}$ and $\mathrm{Ag}-\mathrm{Pt} / \mathrm{TiO}_{2}$ nanoparticles 


\begin{tabular}{|c|c|c|c|c|c|c|c|c|c|c|c|c|c|}
\hline \multirow{3}{*}{ Sample no. } & \multirow{3}{*}{$\mathrm{TiO}_{2}$} & \multirow{3}{*}{$\begin{array}{c}\text { Amount of } \\
\text { platinum } \\
\text { precursor } \\
\text { [mol\%] }\end{array}$} & \multirow{3}{*}{$\begin{array}{c}\text { Amount } \\
\text { of silver } \\
\text { precursor } \\
{[\mathrm{mol} \%]}\end{array}$} & \multirow{3}{*}{$\begin{array}{c}\text { BET } \\
\text { surface } \\
\text { area } \\
{\left[\mathrm{m}^{2} / \mathrm{g}\right]}\end{array}$} & \multicolumn{6}{|c|}{ Crystallite size $[\mathrm{nm}]$} & \multicolumn{2}{|c|}{$\begin{array}{l}\text { Phenol degradation constant } \\
\text { rate }\left[\mathrm{min}^{-1}\right] \cdot 10^{-2}\end{array}$} & \multirow{3}{*}{$\begin{array}{l}\text { Sample } \\
\text { color }\end{array}$} \\
\hline & & & & & \multicolumn{2}{|c|}{$\mathrm{TiO}_{2}$} & \multicolumn{2}{|c|}{$\mathrm{Pt}$} & \multicolumn{2}{|c|}{$\mathrm{Ag}$} & \multirow{2}{*}{$\begin{array}{l}\text { under } \\
\text { UV/Vis }\end{array}$} & \multirow{2}{*}{$\begin{array}{l}\text { under Vis } \\
\lambda>420 \mathrm{~nm}\end{array}$} & \\
\hline & & & & & $\mathrm{a}$ & $\mathrm{r}$ & 111 & 200 & Ag* & $\mathrm{Ag}_{2} \mathrm{O}$ & & & \\
\hline $\mathrm{TiO}_{2}$ & TIP & 0 & 0 & 81 & 10 & - & - & - & - & - & $4.58 \pm 0.28$ & $0.30 \pm 0.02$ & white \\
\hline $\mathrm{TiO}_{2} \mathrm{P} 25$ & P25 & 0 & 0 & 55 & 28 & 33 & - & - & - & - & $4.81 \pm 0.27$ & $0.46 \pm 0.01$ & white \\
\hline $\mathrm{TiO}_{2} \_\mathrm{ST} 01$ & ST01 & 0 & 0 & 250 & 8 & - & - & - & - & - & $4.76 \pm 0.27$ & $0.39 \pm 0.01$ & white \\
\hline $\mathrm{Ag} / \mathrm{TiO}_{2}{ }_{1}$ & TIP & 0 & 2.5 & 84 & 12 & - & - & - & 2 & 12 & $4.96 \pm 0.25$ & $0.28 \pm 0.01$ & beige \\
\hline $\mathrm{Ag} / \mathrm{TiO}_{2} 2$ & TIP & 0 & 4.5 & 87 & 13 & - & - & - & 3 & 13 & $4.72 \pm 0.28$ & $0.52 \pm 0.02$ & grey \\
\hline $\mathrm{Ag} / \mathrm{TiO}_{2} \_3$ & TIP & 0 & 6.5 & 72 & 14 & - & - & - & 14 & 5.1 & $4.94 \pm 0.25$ & $0.81 \pm 0.04$ & grey \\
\hline $\mathrm{Pt}^{\mathrm{T}} \mathrm{TiO}_{2 \_} 1$ & TIP & 0.1 & 0 & 101 & 8 & - & 2 & - & - & - & $4.89 \pm 0.26$ & $1.24 \pm 0.10$ & yellow \\
\hline $\mathrm{Pt} / \mathrm{TiO}_{2} \_2$ & P25 & 0.1 & 0 & 54 & 21 & 31 & - & - & - & - & $4.95 \pm 0.25$ & $1.06 \pm 0.08$ & grey \\
\hline $\mathrm{Pt} / \mathrm{TiO}_{2 \_} 3$ & TIP & 0.5 & 0 & 108 & 8 & - & - & 5 & - & - & $4.97 \pm 0.25$ & $1.84 \pm 0.15$ & yellow \\
\hline $\mathrm{Pt}^{\mathrm{TiO}}{ }_{2 \_} 4$ & ST01 & 0.1 & 0 & 188 & 10 & - & 1 & 3 & - & - & $4.98 \pm 0.26$ & $1.45 \pm 0.10$ & yellow \\
\hline $\mathrm{Ag}-\mathrm{Pt} / \mathrm{TiO}_{2} \mathrm{~T} 1$ & TIP & 0.1 & 2.5 & 68 & 8 & - & 2 & 9 & 4 & 69 & $4.95 \pm 0.25$ & $2.04 \pm 0.13$ & yellow \\
\hline $\mathrm{Ag}-\mathrm{Pt} / \mathrm{TiO}_{2} \mathrm{~T} 2$ & TIP & 0.5 & 2.5 & 93 & 9 & - & 2 & 3 & 6 & 14 & $4.94 \pm 0.25$ & $3.69 \pm 0.20$ & yellow \\
\hline $\mathrm{Ag}-\mathrm{Pt} / \mathrm{TiO}_{2} \mathrm{~T} 3$ & $\mathrm{P} 25$ & 0.5 & 2.5 & 51 & 21 & 31 & 38 & 74 & 12 & - & $4.89 \pm 0.26$ & $1.40 \pm 0.11$ & beige \\
\hline $\mathrm{Ag}-\mathrm{Pt} / \mathrm{TiO}_{2} \mathrm{~T} 4$ & ST01 & 0.5 & 2.5 & 154 & 15 & - & 42 & 145 & 2 & 18 & $4.90 \pm 0.26$ & $1.20 \pm 0.10$ & dark yellow \\
\hline $\mathrm{Ag}-\mathrm{Pt} / \mathrm{TiO}_{2} \mathrm{R} 1$ & TIP & 0.5 & 2.5 & 95 & $9-10$ & - & 9 & - & 5 & - & $4.98 \pm 0.25$ & $3.56 \pm 0.19$ & yellow \\
\hline $\mathrm{Ag}-\mathrm{Pt} / \mathrm{TiO}_{2} \mathrm{R} 2$ & $\mathrm{P} 25$ & 0.5 & 2.5 & 45 & 25 & 24 & 14 & - & 4 & 1 & $4.99 \pm 0.26$ & $1.74 \pm 0.08$ & yellow \\
\hline $\mathrm{Ag}-\mathrm{Pt} / \mathrm{TiO}_{2} \mathrm{R} 3$ & ST01 & 0.5 & 2.5 & 109 & 11 & - & 11 & - & 3 & 3 & $4.98 \pm 0.25$ & $2.33 \pm 0.10$ & yellow \\
\hline
\end{tabular}




\begin{tabular}{|c|c|c|c|c|c|c|c|}
\hline \multirow{3}{*}{ Sample no. } & \multirow{3}{*}{$\begin{array}{c}\mathrm{TiO}_{2} \\
\text { source }\end{array}$} & \multicolumn{3}{|c|}{ Amount of platinum [mol\%] } & \multicolumn{3}{|c|}{ Amount of silver [mol\%] } \\
\hline & & \multirow{2}{*}{$\begin{array}{c}\text { used for } \\
\text { deposition }\end{array}$} & \multicolumn{2}{|c|}{ deposited } & \multirow{2}{*}{$\begin{array}{l}\text { used for } \\
\text { deposition }\end{array}$} & \multicolumn{2}{|c|}{ deposited } \\
\hline & & & EDS & XPS & & EDS & XPS \\
\hline $\mathrm{Pt} / \mathrm{TiO}_{2} \_2$ & $\mathrm{P} 25$ & 0.1 & 0.06 & n.a. & 0 & 0 & n.a. \\
\hline $\mathrm{Pt} / \mathrm{TiO}_{2 \_} 4$ & ST01 & 0.1 & 0.09 & 1.9 & 0 & 0 & 0 \\
\hline $\mathrm{Ag}-\mathrm{Pt} / \mathrm{TiO}_{2} \_\mathrm{T} 1$ & TIP & 0.1 & 0.2 & n.a. & 2.5 & 2.24 & n.a. \\
\hline $\mathrm{Ag}-\mathrm{Pt} / \mathrm{TiO}_{2} \_\mathrm{T} 2$ & TIP & 0.5 & 0.34 & 1.8 & 2.5 & 0.38 & 0.3 \\
\hline $\mathrm{Ag}-\mathrm{Pt} / \mathrm{TiO}_{2} \_\mathrm{T} 3$ & $\mathrm{P} 25$ & 0.5 & 0.23 & 3.0 & 2.5 & 0.34 & 0 \\
\hline $\mathrm{Ag}-\mathrm{Pt} / \mathrm{TiO}_{2} \_\mathrm{T} 4$ & ST01 & 0.5 & 0.58 & 3.1 & 2.5 & 0.38 & 0 \\
\hline
\end{tabular}

n.a.- not analyzed 


\begin{tabular}{|c|c|c|c|}
\hline & \multicolumn{3}{|c|}{ Zone of inhibition (mm) } \\
\hline & $\begin{array}{c}\text { Candida albicans } \\
\text { ATCC } 10231 \text { (YNBG) }\end{array}$ & $\begin{array}{c}\text { Escherichia coli } \\
\text { ATCC } 10536 \text { (TSB) }\end{array}$ & $\begin{array}{c}\text { Staphylococcus aureus } \\
\text { ATCC } 6538 \text { (TSB) }\end{array}$ \\
\hline DMSO & 0 & 0 & 0 \\
\hline $\mathrm{TiO}_{2}$ & 0 & 0 & 0 \\
\hline $\mathrm{Ag} / \mathrm{TiO}_{2} \_1$ & 9 & 19 & 18 \\
\hline $\mathrm{Ag} / \mathrm{TiO}_{2 \_} 2$ & 9 & 16 & 13 \\
\hline $\mathrm{Ag} / \mathrm{TiO}_{2} \_3$ & 9 & 21 & 19 \\
\hline $\mathrm{Pt} / \mathrm{TiO}_{2} \_3$ & 0 & 0 & 0 \\
\hline Ag-Pt/TiO ${ }_{2} \mathrm{~T} 2$ & 11 & 0 & 0 \\
\hline Ag-Pt/TiO ${ }_{2}$ T3 & 9 & 9 & 9 \\
\hline $\mathrm{Ag}-\mathrm{Pt} / \mathrm{TiO}_{2} \mathrm{~T}_{4}$ & 9 & 15 & 0 \\
\hline $\mathrm{Ag}-\mathrm{Pt} / \mathrm{TiO}_{2} \_\mathrm{R} 1$ & 9 & 15 & 12 \\
\hline $\mathrm{Ag}-\mathrm{Pt} / \mathrm{TiO}_{2} \_\mathrm{R} 2$ & 9 & 14 & 11 \\
\hline $\mathrm{Ag}-\mathrm{Pt} / \mathrm{TiO}_{2} \mathrm{R} 3$ & 9 & 14 & 11 \\
\hline
\end{tabular}




\begin{tabular}{|c|c|c|c|}
\hline & \multicolumn{3}{|c|}{ Minimum inhibitory concentration $\left(\mu \mathrm{g} \cdot \mathrm{cm}^{-3}\right)$} \\
\hline & $\begin{array}{c}\text { Candida } \\
\text { albicans } \\
\text { ATCC } \\
10231 \\
\text { (YNBG) }\end{array}$ & $\begin{array}{c}\text { Escherichia } \\
\text { coli } \\
\text { ATCC } 10536 \\
\text { (TSB) }\end{array}$ & $\begin{array}{c}\text { Staphylococcus } \\
\text { aureus } \\
\text { ATCC } 6538 \\
\text { (TSB) }\end{array}$ \\
\hline $\mathrm{TiO}_{2}$ & $>256$ & $>256$ & $>256$ \\
\hline $\mathrm{Ag}-\mathrm{TiO}_{2} \_1$ & 8 & 125 & 64 \\
\hline $\mathrm{Ag}-\mathrm{TiO}_{2} \_2$ & 32 & $>256$ & $>256$ \\
\hline $\mathrm{Ag}-\mathrm{TiO}_{2}{ }_{3}$ & 8 & 256 & 64 \\
\hline Pt-TiO ${ }_{2} 3$ & $>256$ & $>256$ & $>256$ \\
\hline $\mathrm{Ag} / \mathrm{Pt}-\mathrm{TiO}_{2} \mathrm{~T}_{2}$ & 32 & $>256$ & $>256$ \\
\hline $\mathrm{Ag} / \mathrm{Pt}-\mathrm{TiO}_{2} \mathrm{~T}_{3}$ & 64 & $>256$ & 256 \\
\hline $\mathrm{Ag} / \mathrm{Pt}-\mathrm{TiO}_{2} \mathrm{~T}_{4}$ & 32 & $>256$ & 256 \\
\hline $\mathrm{Ag} / \mathrm{Pt}-\mathrm{TiO}_{2} \_\mathrm{R} 1$ & 8 & $>256$ & 256 \\
\hline $\mathrm{Ag} / \mathrm{Pt}-\mathrm{TiO}_{2} \_\mathrm{R} 2$ & 64 & $>256$ & $>256$ \\
\hline $\mathrm{Ag} / \mathrm{Pt}-\mathrm{TiO}_{2} \mathrm{R}_{3}$ & 16 & $>256$ & $>256$ \\
\hline
\end{tabular}

